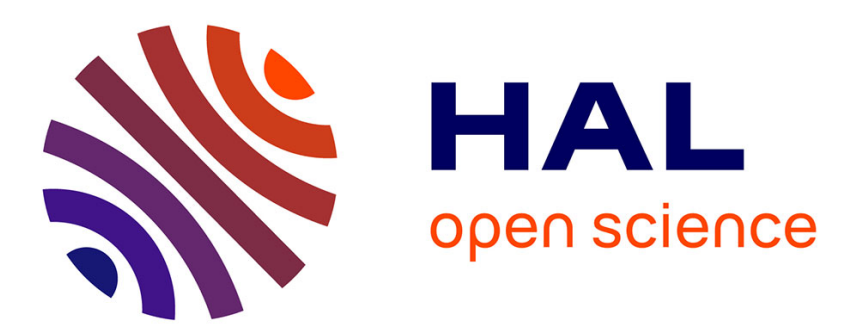

\title{
An extremist autarky: the systemic separation of the French Extreme Right
}

Gilles Ivaldi, Jocelyn A.J. Evans

\section{To cite this version:}

Gilles Ivaldi, Jocelyn A.J. Evans. An extremist autarky: the systemic separation of the French Extreme Right. Southern European Society and Politics, 2005, Vol.10 ( ${ }^{\circ} 2$, July, Special Issue: The South European Right in the 21st Century: Italy, France and Spain), pp.351-366. halshs-00090108

\section{HAL Id: halshs-00090108 https://shs.hal.science/halshs-00090108}

Submitted on 28 Aug 2006

HAL is a multi-disciplinary open access archive for the deposit and dissemination of scientific research documents, whether they are published or not. The documents may come from teaching and research institutions in France or abroad, or from public or private research centers.
L'archive ouverte pluridisciplinaire HAL, est destinée au dépôt et à la diffusion de documents scientifiques de niveau recherche, publiés ou non, émanant des établissements d'enseignement et de recherche français ou étrangers, des laboratoires publics ou privés. 


\title{
An extremist autarky: the systemic separation of the French Extreme Right
}

\author{
Jocelyn AJ Evans
}

and

Gilles Ivaldi

\section{Introduction}

The 2002 legislative and presidential elections bore testimony to the consolidation of the position of the Extreme Right in the French political system as a strong mobilisatory force, despite hasty predictions of decline in 1999 subsequent to the split by the Mouvement National Républicain (MNR) from the Front National (FN). Beyond the specific circumstances of the elections which allowed Jean-Marie Le Pen to progress to the second round, but which saw a relative drop for FN and MNR candidates in the subsequent legislative ballots, the Extreme Right vote has a number of specific characteristics which raise it above the status of a simple protest vote which has so often been used to characterise Le Pen and his party's support. In the subsequent 2004 Parliamentary and regional elections, the party performed equally strongly relative to its 2002 legislative score, unlike its Moderate Right counterparts who experienced a major defeat at the hands of the Left in both.

The FN has undoubtedly enjoyed a renaissance on the back of these elections, particularly in its hegemony of the Extreme Right space over the essentially moribund party led by Bruno Mégret. However, the party seems as isolated as ever from the rest of the party system, and in particular from the mainstream Right. It has been incapable of building itself a legislative role consonant with its electoral capital, and has consequently only ever been able to exploit its nuisance and protest potential, instead of joining its moderate neighbours in the corridors of power, in the way that the Italian Extreme Right has managed.

To this extent, the electoral fortunes of the two Extreme Right parties are of proportionately greater interest in studying these parties given that in the intervening periods, media blackouts and non-insertion in power, the parties' presence declines considerably. This paper will consider the implantation of the FN in its current role as anti-system party par excellence in the French system, and look at the institutional and electoral reasons which prevent it from becoming part of the Right bloc to which in many ways it clearly belongs.

\section{The electoral implantation of the Extreme Right}

(Table 1 about here.)

The electoral results of the FN and MNR in May / June 2002 are worth considering as the culmination of the FN's development since its first successes in the 1980s (see Table 1). Gathering $19.2 \%$ of the first round presidential vote, Jean-Marie Le Pen and Bruno 
Mégret once again confirmed the electoral potency of a political stream anchored firmly at the national as well as sub-national level. The drop in the legislative elections, where the parties gathered $12.4 \%$ of the first round vote across France, paradoxically points to the strength of loyalty of a core of Extreme Right voters who have given the FN one of the most stable partisan supports in France (Mayer 2002).

The 1999 European elections followed by the 2001 municipal and cantonal elections, had already given some indication of the enduring strength of the two Extreme Right parties. In June 1999, their joint scores accounted for $9.1 \%$ of the vote - their worst result ever in a European ballot, but not as disastrous as some had predicted so soon after the split in the party between Le Pen and Mégret. What is more, the presence of the souverainiste Pasqua / De Villiers list and a high level of abstention also meant that just under onetenth of the vote was a more than credible result under the circumstances. ${ }^{1}$ In the municipal elections of March 2001, the two Extreme Right parties experienced a small downturn on the 1995 result of $14.2 \%$, with the FN receiving $12.2 \%$ and the MNR $11.3 \%$ in the communes where they fielded candidates. In total, the party lost on average $3.2 \%$ in the 262 towns with over 5000 inhabitants where they stood for election in both 1995 and 2001. Again, this drop is significant, but given the context for the two splinters of the originally cohesive FN, far from the 'worst-case scenario'. Indeed, in the cantonal elections, the $10 \%$ of the vote won by the two parties is almost identical to the FN's score in 1994 election. ${ }^{2}$ From the party system perspective, the 2002 results clearly demonstrated the institutionalisation of the Extreme Right, and its ability to retain a foothold in its former bastions despite the schism.

(Table 2 about here.)

Despite the MNR presence, the FN managed to present candidate in all of the 2002 mainland constituencies, with the exception of Bas-Rhin. In total, 566 FN representatives stood for election. Similarly, the mégretiste party stood in 569 constituencies (547 of them on the mainland) on the MNR ticket. As Table 2 shows, the two Extreme Right parties have relatively similar sociological profiles to their candidates. Most notably, both rose to the challenge presented by the gender parity laws with some of the highest levels of 'feminisation' amongst parties in France. In other respects, the parties are even more similar - average age over 50, over-representation of the self-employed, heads of business and the retired, backed up by white-collar employees and other inactive groups (mainly women).

The second important point of convergence lies in the almost identical manifestos presented by the two parties - hardly a surprise, given Bruno Mégret's importance in defining FN ideology prior to 1999. Both revolved around familiar national-populist themes: immigration and xenophobia; authoritarianism, moral conservatism and hard-line law-and-order policy; a mixed economic programme, combining anti-fiscal liberalism and national protectionism against globalisation, the United States and free trade; and a continued virulent anti-party stance, designed to delegitimise the mainstream parties and elites, and focusing on their collusion in cohabitation. ${ }^{3}$ 
These themes were certainly in line with the aspirations and desires of the Extreme Right electorate. Le Pen's voters in the first round of the presidential elections were particularly worried by the issues of law-and-order $(74 \%)$, immigration $(60 \%)$ and unemployment (31\%), a standard triptych for FN voters since the 1984 European elections. ${ }^{4}$ Mégret voters invoked similar issues - law-and-order (68\%), immigration (53\%) and justice $(46 \%)$, in keeping with their candidate's hard line on delinquency and immigration (IPSOS-Vizzavi-Le Figaro-France 2 survey, 21 April 2002).

Considering the stability of the issues supporting Extreme Right voting over a 20-year period, it is also important to highlight the growing loyalty of a pool of FN voters over the same period. Le Pen's party has managed increasingly to stop relying upon very volatile one-time voters and instead stabilise a pool of voters accounting for around 80$85 \%$ of his electorate between the two elections. ${ }^{5}$ By 2002 , one could speak of a large group of voters manifesting an almost anachronistic type of party identification for the FN. In the first round of the 2002 presidentials, 90\% of Le Pen's 1995 voters remained with one of the two Extreme Right candidates. ${ }^{6}$ In total, Extreme Right leaders took back $86 \%$ of the FN support from 1997.

Table 3 about here.

This gradual stabilisation of the Extreme Right's support has been accompanied by a shift in the sociodemographic profile of this electorate, starting in the 1988 presidential elections and clearly visible by the 2002 vote (see Table 3). In terms of gender, the Extreme Right electorate has remained consistently male, the gap being noticeable in both rounds of the 2002 election ( +7 and +15 respectively) and to a lesser degree in the legislative elections (+3). The FN and MNR also continue to recruit support amongst the youngest strata, in particular those under 25 who are traditionally most open to Extreme Right voting.

The age shift has been accompanied by a major sea-change in the occupational profile of the parties. Since the late 1980s, electoral support for the old Poujadist deputy has undergone a noticeable proletarianisation, including an important contingent of workingclass voters together with the classic petty bourgeois stream - artisans, tradesmen, small businessmen - who have supported the FN on the basis of neo-liberal economic views, and especially the anti-tax issue, prevalent in the party's early programme (Perrineau, 1997; Evans, 2000;; Mayer, 2002).

This occupational synthesis is one of the key novelties associated with many successful Extreme Right parties (Kitschelt, 1994; Evans, 2005), and is certainly characteristic of Le Pen's first round electorate $-29 \%$ of the self-employed and almost a third of workers. This working-class profile is logically linked to the low cultural and economic capital attributes of these voters - the FN and MNR are particular over-represented amongst the lowest educational strata and are under-represented amongst those with a higher education. Equally, those with the lowest incomes are most likely to support the Extreme Right. 
The importance attached to this development in the party's electorate over the years is symbolised by the sudden swerve in the FN's party programme after the 1995 presidential election. ${ }^{7}$ Having become 'the first party of the workers', the FN leadership took great care to adopt a number of socially protectionist policies from the left, placing itself firmly in the camp which looks after the under-class and promotes an economic vision hostile to capitalism, globalisation, free-trade and the general liberalisation of the world economy (Swyngedouw and Ivaldi, 2001). The increased vote of the party amongst these 'modernisation losers' bears witness to the success of this strategy $-38 \%$ of the unemployed in the presidential first round for Le Pen; a quarter of the lowest income band; and $30 \%$ of the unemployed vote for the FN in the subsequent legislatives.

(Table 4 about here.)

Finally, the geographical spread of the FN vote is also stable in its key strongholds - an urban France faced with deindustrialisation, unemployment, an immigrant population and low law-and-order. In 2002, the FN and MNR votes fit the contours of the traditional national-populist areas: the Paris region, Nord Pas-de-Calais, Alsace, Rhône-Alpes and the Mediterranean sea-board (see Table 4). ${ }^{8}$ Such patterns were matched in the regional elections of 2004, where the FN scored over $19 \%$ of the vote - against an overall average of 13\% - in Alsace, Provence-Alpes-Côte d'Azur (PACA) and Nord Pas-de-Calais.

\section{The 2002 context: presidential flow, legislative ebb}

In spring 2002, the Extreme Right vote again represented the totality of worries and traumas which urban post-industrial France had experienced through its years of economic recession and unemployment, breakdowns in law-and-order and painful facingup to modernity. As elsewhere in Western Europe, the success of the FN betrayed an enormous representational abyss cutting off elites from their citizens. ${ }^{9}$ Many French people's questions about economic insecurity, delinquency, threats to the French model of social justice, and the apparent inability of the main governing parties to address the separation of society into 'two Frances' and the emergence of a new European and world order all lay behind this.

Nevertheless, the specific context in 2002 of 'simultaneous' presidential and legislative elections was key. Unlike other party formations in the systems, the Extreme Right's electoral success remains linked to conjunctural dynamics, and to the state of party competition and whether it will offer a propitious political opportunity structure to such peripheral actors. In this respect, two key 'moments' of the 2002 elections are worth studying in depth - the progression of Le Pen to the second round of the Presidential elections, and the legislative fallback.

\section{The shock of 21 April 2002}

In garnering almost $20 \%$ of the vote (> 5400000 voters) in the first round of the presidential election, the Extreme Right parties clearly made the most of their electoral potential and found the resources necessary to achieve their best result ever. ${ }^{10}$ In 
comparison to the previous presidential election of 1995, the FN and MNR's vote increased by 900901 votes. In April 2002, Le Pen came first in almost one-third of mainland departments - 35 in total - and surpassed the $20 \%$ threshold in $28 \%$ of constituencies.

The increase in FN / MNR vote went beyond the classic lepéniste limits: the gains for both leaders were spread across the entire country, with a rise in no less than $98 \%$ of mainland constituencies, and most notably in certain target zones, particularly rural and rural-urban regions. ${ }^{11}$ A regression analysis of the evolution in abstention and vote for the main party formations relative to presidential voters in 1995 and 2002 clarifies the complex nature of the Extreme Right's success. The latter appears to have gained amongst former abstainers located in the least participatory regions, from the reduction in left-wing candidates and the decreased influence of the Moderate Right. ${ }^{12}$ This pattern is confirmed by IPSOS exit polls, with Le Pen and Mégret's electorates including 5\% of Robert Hue, $7 \%$ of Lionel Jospin, $16 \%$ of Edouard Balladur and 12\% of Jacques Chirac's first round voters from 1995 (IPSOS-Vizzavi-Le Figaro-France 2, 21 April 2002).

These results are directly linked to the logic of the 2002 presidential election and the socio-political issues which framed this vote. As we have already noted, a major motivation for the Extreme Right vote, and particularly in 2002, was the growing feeling of insecurity. An issue of polarising salience but largely ignored by the mainstream parties until recently, this question has increasingly dominated public life not least due to the media's melodramatic and sometimes hysterical reporting of certain events. A basic demand for security exacerbated by the growth in delinquency has proved remediable at least in the public's eyes - only through a repressive authoritarian discourse amply and almost exclusively provided by the Extreme Right over the last 30 years. ${ }^{13}$

The disruption of the international stage since 9/11 has also played an amplifying role with regard to worries over delinquency. The simultaneity of discussion over both antiterrorist military actions and the need to toughen up on immigration laws has confused the two in the public's mind and helped forge a fallacious link between crime and immigration. The dismantling of Al Qaeda 'networks' in France has exaggerated the internal threat of terrorism and conversely seems to legitimise the FN and MNR's antiIslamic rhetoric. The slowing of economic growth and the new rise in unemployment have both added to this general impression of crisis, and more specifically the weakening in credibility of the main party leaders' programmes for regeneration presented in their election manifestos.

From the political perspective, the first round of the 2002 presidential election remains notable for its high level of abstention $(+6.8 \%$ on 1995), growing party fragmentation, the proportionalisation of choice ${ }^{14}$ and the growing rejection of the governing parties. Such factors have benefited a number of marginal actors, and not just the FN and MNR, as we have noted: the exceptionally high scores for the three Trotskyite candidates, totalling $10.4 \%$, were also a sanction against the tired cohabitation of the previous administration which had been adjudged impotent and immobile through the convergence of ideology and actions of Lionel Jospin, its Prime Minister, and Jacques Chirac, its 
president. In this respect, the anti-establishment rhetoric of the Extreme Right parties has consistently demonstrated an aptitude for exploiting the confusion and loss of benchmarks amongst the mainstream caused by 15 years of hyper-alternance. ${ }^{15}$

The last element to this presidential success is the strengthening of the Extreme Right vote outside its usual areas of success - the East, the North and the Mediterranean seaboard - and in particular the rural / rural-urban zones which had never previously constituted particularly fertile ground for national-populism. For example, as many as $26 \%$ of farmers and $23 \%$ of rural inhabitants voted for Le Pen and Mégret together (IPSOS-Vizzavi-Le Figaro-France 2, 21 April 2002). In these areas, the Extreme Right seems to have been able to attract a new clientele not just on the basis of the delinquency issue, which nowadays extends well beyond towns and cities, but also on issues of antitax, anti-globalisation and anti-Europe, by appealing to an electorate worried about the future developments in the CAP, particularly after Enlargement.

In 2002, the cleavage opposing pro- and anti-Maastricht sentiment resurfaced in an Extreme Right guise, symptomatic of a general anti-system malaise amongst a certain section of the French electorate (Belot and Cautres, 2004). Across 555 mainland constituencies, the Le Pen vote in the first and second rounds appeared significantly correlated $(+0.418$ and +0.594 , respectively) with the 1992 No vote in the Maastricht referendum - a stronger association than in the 1995 election, for example $(+0.256)$. The zones with the greatest increase in Extreme Right vote between 1995 and 2002 are equally those with the highest levels of No vote. In the second round of the election, the FN candidate managed to win 31\% of those who had voted No in September 1992 (IPSOS-Vizzavi-Le Figaro-France 2, 5 May 2002). ${ }^{16}$

The second round of the presidential election underlined, however, the limits to this Extreme Right resurgence, and clearly delineated the true constituency of these parties. The 'divine surprise' of 21 April engendered some unrealistic hopes amongst supporters of Le Pen, and had pushed the candidate himself to predict a second-round vote of onethird of the voters - a bar he missed by some margin, winning only $17.8 \%$. Le Pen managed to hold onto his electorate from the first round, but added a meagre 54168 votes to the score of the two first-round Extreme Right candidates combined. ${ }^{17}$ Only in just over one-third of mainland constituencies did he break through the $20 \%$ ceiling and made modest gains in only around half.

This situation probably mirrors the limits of a 'protest' explanation of the Extreme Right vote. More than 5.5 million voters continued to express their disaffection with mainstream candidates and parties via Le Pen in the deciding round of a major election and hoped to see political influence derive from the potential outcome of their candidate doing much better than simply the combined total of the two first-round scores. This solidity is all the more surprising given the context of anti-FN demonstrations of an unprecedented level, together with calls for an anti-Extreme Right vote from personalities across all spheres of public life. It is still difficult to estimate precisely the extent to which the anti-Le Pen and pro-Republican discourse of the campaign contributed to stifling any hope the FN leader had of increasing his score. Despite a process of 
ideological 'cleaning' and a search for respectability, Le Pen appears to have continued to suffer from a lack of governing credibility, together with a reputation as an Extreme Right militant - and a radical one at that.

\section{The legislative reversal}

Next to the presidential elections, the outcome of the legislative elections seems like a relative failure for the $\mathrm{FN}$, which had been seen on the eve of the elections as a possible deciding factor in more than 300 second-ballots and three-way run-offs. At the first round, the FN managed $11.12 \%$ of the vote, and the MNR could only scrape together $1.08 \%$. In total, the Extreme Right lost over 2 million voters relative to the presidentials, and dropped back to its 1993 level.

In the end, the FN could only stand in 37 second-round ballots ( 27 of these straight twoway run-offs) and won none of these. Its figureheads tried in vain to mobilise voters for the second round - Bruno Gollnisch in the Rhône; Marine Le Pen in the Pas-de-Calais; Marie-France Stirbois in Nice, and Jean-Claude Martinez in the Hérault. Others, such as Martine Lehideux in Paris or Carl Lang in Nord did not win sufficient votes to progress to the second round. In Orange, Jacques Bompard, re-elected mayor in 2001 and the main chance of winning a deputy, only received $42.4 \%$ of the second-round vote.

(Table 5 about here.)

For its part, the MNR could not capitalise upon its local strength, notably in the Bouchesdu-Rhône and Alsace. Bruno Mégret was soundly beaten in Vitrolles, with only $18.6 \%$ of the vote, as compared with $35.5 \%$ in 1997. In Gardanne, Damien Bariller managed only a meagre $3.7 \%$ (Table 5). As evident as it is, this downturn for the Extreme Right, and in particular for the FN, should nevertheless be seen in the context of the legislative elections of 2002, just as Le Pen's success needs to be interpreted in a similar manner through party competition and the political opportunity structure open to the two parties.

Recall, firstly, that legislative elections in France have never been auspicious for the Extreme Right, or for new and emerging parties more generally. The majoritarian electoral system, the need for a local power-base and the possession of notables have all tended to advantage the major party groupings at the expense of more peripheral actors. In 1988, for example, the surge in support for Le Pen at the presidential election was not followed by an upturn in the FN vote at the subsequent legislatives. In 2002, the resistance to the FN demonstrated by the massive Republican vote in the second round gave little hope to FN candidates of seeing their names on the second-round ballot-paper. Add to this the impossibility of any cooperation with the new Parliamentary majority gathered behind the re-elected president, and it is easy to see why many FN voters would have preferred to abstain than bother with a vote 'wasted' in advance.

At the same time, another portion of the Le Pen and Mégret voters from the month before could well have been attracted by the possibility of a tactical vote for the Moderate Right to counter the risks engendered by votes spread too thinly. In fact, the rallying dynamic 
initiated by the UMP worked as a veritable 'victory machine', once again demonstrating the strength which the Right enjoys when it is not riven by discord. By presenting single candidates in almost $93 \%$ of constituencies, the young UMP modified political supply enough to win back a number of prodigal Extreme Right defectors, and offer voters a landslide majority to dispense with the highly unpopular cohabitation predecessor.

The personality of the Prime Minister, Jean-Pierre Raffarin, and the emphasis put on the notions of 'closeness' and 'action' by the government clearly coincided with the electorate's wishes, though the extent to which Raffarin has been able to exploit this successfully over the past three years is doubtful, as Kuhn notes elsewhere in this volume. From an ideological perspective, the move to the Right by the new executive on security, taxation and a critique of cohabitation certainly convinced a segment of the petty bourgeoisie to return from Le Pen and Mégret.

A regression analysis of the evolution in abstention and the main party groupings in the legislatives - Extreme Left, Pluralist Left, Moderate Right and Extreme Right - between the first presidential and legislative rounds broadly confirms the hypothesis that the Extreme Right lost to both abstention and the Moderate Right. ${ }^{18}$ Surveys carried out the day of the vote corroborate these ecological analyses: of 100 Le Pen voters at the first round of the presidential elections, 28 declared that they had not voted at the legislative elections (as opposed to only 11 mégretiste abstainers). The $\mathrm{FN}$ in particular seems to have lost the least politicised component of its presidential pool. As for those Extreme Right voters who turned out: $22 \%$ of Le Pen supporters preferred to pick a Moderate Right or Centre candidate, as opposed to $72 \%$ who stayed faithful to their party. For its part, almost a third of the Mégret electorate preferred the Moderate Right (IPSOSVizzavi-Le Figaro-France 2 survey, 9 June 2002).

The Extreme Right balance of power and systemic isolation

Concerning intra-Extreme Right competition between the two parties, this had very little effect on the first round of the legislative elections, except in a handful of high-profile constituencies where brotherly hate was a factor involved in loss at the first round. If we hypothesise an anti-monde with a single Extreme Right party in this election - simply by adding the two parties' scores together, and ignoring any electoral added value potentially accrued from unity - this party would have just reached the $12.5 \%$ threshold necessary to progress to the second round in a mere 18 extra constituencies. ${ }^{19}$

Overall, the mégretiste faction had very little effect on the national-populist electorate, indicating the blatant failure by its leader to build a 'national Right' bloc between the Moderate Right and the Extreme Right, along the lines of the MSI-AN in Italy. Mégretisme failed in particular to resolve the fundamental contradiction between Le Pen's anti-system populism and any sort of technocratic respectability or credibility. Since the split of 1999, the FN seems to have been able to assert its hegemonic position on the Extreme Right (Ivaldi 1999b). The European elections in June 1999 confirmed a ratio of 1/3-2/3 in favour of Le Pen's party with 5.8\% ahead of Mégret's 3.3\%. 
Electoral defeat today has been joined by severe financial and legal difficulties. In March 2000, the Paris Cour d'Appel confirmed the decision to grant legal ownership of the FN name and logo to Le Pen and deprive the mégretiste organization of any share of the FN's coffers. The pitiful European score in 1999, followed by an equally disastrous showing at the 2002 presidentials, have increased the burden of a party which cannot pretend to be able to cover its campaign costs. In the summer of 2002, the MNR leader saw the collapse of his citadel in Vitrolles and the forced departure of his wife from the town hall after the annulment of the municipal election result of 2001. All this against the context of revelations of close links with certain radical Right-wing groups and a failed attempt on the life of Maxim Brunerie, a former MNR candidate in Paris.

These successive blows to a party already weakened by its electoral failure places a large question-mark over the political future of the MNR and its leaders. It leaves open the possibility of an eventual return to the FN of part of the activist base who originally believed in the mégretiste project. This has not allowed the FN to leave its political isolation, however. If the 2002 elections have taught us anything, it is the paradox that, despite its electoral success, the FN remains confined to the margins of mainstream politics, and is even less qualified now to form any alliance with the Moderate Right.

Yet this is in spite of the FN's strategy after the second round of the presidential elections to hold out its hand to any Moderate Right-wingers who would contemplate an alliance with the Extreme Right, in the (misguided) belief that they could expect a positive response from a parliamentary Right worried about the Extreme Right's legislative potential. In 2002, the notably more conciliatory tone of the FN, as compared with its scorched earth policy between 1995 and 1997, showed the will of the party to 'relocate' (Ivaldi 2002). Its failure has been in no small part due to the refusal by Moderate Right leaders, and in particular Jacques Chirac, to countenance such cooperation.

\section{Conclusion: what future for the Extreme Right in France?}

The chapter of the 2002 presidential and legislative elections closes on the electoral consolidation of the Extreme Right and its continued banishment on the margins. Beyond strictly conjunctural effects, the main lessons from these elections encourages us to consider the possibility of the progressive implantation of an ideological family which thus far has remained silent and held outside mainstream political discourse. Whilst there is debate over the extent to which the Extreme Right should be considered a separate political bloc (Andersen and Evans, 2003; Grunberg and Schweisguth, 2003), there is undoubtedly a political constituency which sees its political views best represented by a party which is held at arm's length by its mainstream neighbours. In other countries where the Extreme Right has enjoyed similar levels of success to the FN during the 1990s, the weight of numbers has seen the parties in two cases - Italy and Austria - push their way into national legislative positions, and in two other cases - Denmark and Norway - become highly influential policy-brokers in Parliaments with small governing majorities.

In France, the institutional framework and the particularly vituperative hostility to a party that has made no concessions on the radicality of its discourse has ensured that the 
electoral weight of the party has been unable to provide any sort of legislative return. Indeed, in the 2004 regional elections, a relatively strong return - although one which saw a drop of $5 \%$ on its 1998 score - provided no subnational governmental positions either, with the Left dominating 19 of the 22 regional councils and clearly never expected to extend a coalition hand to the FN as the UDF had done six years previously.

But electoral reforms prior to these elections meant that the UDF would not have needed to do this to retain control of regional councils, either: the changes in the system, although originally rejected by the Constitutional Council and consequently modified in a more moderate version, were expressly designed to give the winning list a premium of seats to ensure a majority without necessary recourse to the FN, and a higher first-round threshold for standing in the second round, to reduce the number of triangulaires. 155 seats displayed the loyalty of its core electorate once more, but the bargaining position of 1998 had evaporated (Delwit, 2004: 585).

In similar vein to Le Pen's ineligibility to stand in the PACA region due to non-proof of residence, the politico-institutional culture excludes the Extreme Right from powersharing as a matter of course. Whether this entrenches the loyalty of the self-perceived exclus who support the FN is a moot point. What is certain is that it limits the FN's ability to influence and collude at the national and, increasingly, at the subnational level. Its survival then, similar to the PCF in the post-war period, relies upon its ability to construct a social and political microcosm which it can use to encapsulate its supporters and provide a raison d'être beyond a simple protest every couple of years at election time. Unlike the PCF, however, the FN lacks external support and collusion to help it in this.

Beyond this, the ideas of the FN's leader are shared by a broad proportion of the electorate, and have entered the realm of public debate since the 1980s. ${ }^{20}$ However, such issues have now been absorbed by the mainstream parties - on law-and-order, for instance, Nicolas Sarkozy has adopted a strongly conservative-authoritarian line on crime at least partly in an attempt to steal the FN's thunder on this issue. On other issues, such as Europe, there is evidence that the party's hard-line stance is a function of Jean-Marie Le Pen's own perspective - on his succession, others will not necessarily retain such a stance. $^{21}$ The possibility of the FN - or indeed the MNR - winning new support on this basis seems limited, then. Its strength consequently lies in the loyalty of its core support, around $10 \%$ of the French electorate. If the party can retain this, through social and political encapsulation, then its existence in glorious isolation is assured. Whether it can continue to provide sufficient returns to these voters in such political isolation seems less assured.

\section{$\underline{\text { Notes }}$}

1 Surveys from 1999 confirm a large number of former FN voters amongst the PasquaDe Villiers support: between 10 and 17\%, according to the survey (Ivaldi, 1999a).

2 To boot, the Extreme Right won symbolic victories in Orange, Marignane and Vitrolles. In Orange, the incumbent mayor, Jacques Bompard (FN), was re-elected at the first round with almost 60\%. Daniel Simonpieri (MNR) won with over 65\% of the vote 
against the Moderate Right candidate Guy Martin, who progressed to the second round after the PS candidate stood down. In Vitrolles, Catherine Mégret won with $45.3 \%$ in a three-way run-off against the Moderate Left and Right.

3 For a detailed analysis of the ideological content of the Extreme Right programme, see Ivaldi (2001).

4 Recall that, for two-thirds of the 1997 FN electorate, unemployment and immigration were the two principal issues related to Extreme Right vote (CSA-Le Parisien survey, 26 May 1997).

5 In the first round of the 1997 legislative election, FN candidates received more than $80 \%$ of their support from those who had voted Le Pen two years previously.

6 Similar data have been provided by the Institut Louis-Harris: in the first round of the presidential election, Jean-Marie Le Pen kept $83 \%$ of his 1995 electorate, as well as $5.5 \%$ who moved to Mégret (Louis-Harris-Libération-AOL survey, 21 April 2002).

7 On the doctrinal change, see Ivaldi (1998).

8 The geographical spread of the Extreme Right vote has proved remarkably stable, as correlation coefficients amongst the 555 mainland constituencies demonstrate - between the first rounds of the 1995 and 2002 presidential elections $(r=0.916)$ and the 1997 and 2002 legislative elections $(r=0.903)$.

9 For a comparison of European electoral dynamics amongst Extreme Right parties, see Evans and Ivaldi (2002).

10 This achievement is all the more impressive given the effective media blackout imposed upon Le Pen and Mégret subsequent to the party split in 1999, which presented them with very little campaign space, the media concentrating on the two presumed second-round candidates, Jacques Chirac and Lionel Jospin. Indeed, much of the columnspace allocated to Le Pen emphasised the problems he was having in collecting the requisite number of signatures for his candidacy, and suggested he might repeat the debacle of 1981 when he was unable to stand for this reason.

11 The correlation between 1995 and 2002 Extreme Right vote increase and vote in 1995 is indeed negative $(\mathrm{r}=-0.121, \mathrm{p}<0.01)$

12 Linear regression on 555 mainland constituencies: $\mathrm{R} 2=0.67$; t-values: abstention (20.995); Moderate Left presence (-22.425); Moderate Right presence (-21.173), all significant at $\mathrm{p}<0.001$.

13 The Extreme Right's issue-ownership of criminality and law-and-order is a theme common to parties across Europe (Ivaldi, 2002).

14 On the concept of 'proportionalisation' in a majoritarian context, see Parodi (1997).

15 For a discussion of hyper-alternance, see Evans and Ivaldi (2002).

16 On growing implantation of Europe as a potential cleavage in France (unlike other EU member-states), see Andersen and Evans (2005).

17 Geographically, the Le Pen vote at the second round covered almost exactly the same zones as the first-round vote.

18 Linear regression on 555 mainland constituencies: R2 $=0.67$; t-values: abstention (27.205); Moderate Left presence (-12.601); Moderate Right presence (-18.720), all significant at $\mathrm{p}<0.001$.

19 This would also have eliminated the fiascos which hamstrung two of the major personalities: in Vitrolles, Bruno Mégret himself would doubtless have won the first 
round ahead of the PS and UMP, had the FN candidate not 'stolen' $13.3 \%$ of his vote. Conversely, in the 20th constituency of Nord, Carl Lang would have progressed to the second round if he had enjoyed the support of the 431 voters who chose his MNR rival. 20 An analysis of SOFRES survey results about support for Le Pen's ideas over the period 1984-2002 demonstrate a stable core of support of between 20 and 25\% of respondents who declare themselves to be in agreement with the Extreme Right's policystances (SOFRES-Le Monde-RTL, 23-24 May 2002).

21 Marine Le Pen, his daughter and possible successor at the helm of the party, has publicly stated that the FN must adapt to context and consequently espouse a more proEuropean line (Evans 2005b).

\section{$\underline{\text { References }}$}

Andersen, R. and J. Evans (2003) 'Values, cleavages and party choice in France, 19881995' in French Politics, vol. 1 no. 1, pp. 83-114.

Belot. C. and B. Cautrès (2004) 'L'Europe, invisible mais omniprésente', in B. Cautrès and N. Mayer (eds.) Le nouveau désordre électoral. Les leçons du 21 avril 2002, Paris, Presses de Sciences Po.

Delwit, P. (2004) 'The March 2004 regional elections in France: terms for a transfer of power', in Regional and Federal Studies, vol. 14 no. 4, pp.580-590

Evans, J. (2000) 'Le vote gaucho-lepéniste: le masque extrême d'une dynamique normale' in Revue Française de Science Politique, vol.50 no. 1, pp.21-51.

Evans, J. and G. Ivaldi (2002) 'Les dynamiques électorales de l'extrême-droite européenne' in Revue Politique et Parlementaire, no. 1019, July-August, pp. 67-83.

Evans, J. (2005a, forthcoming) 'The dynamics of social change in Radical Right-wing Populist party support' in Comparative European Politics, vol. 3.

Evans, J. (2005b, forthcoming) "La politique du dehors avec les raisons du dedans": foreign and defence policy of the French Front National' in P. Burrin and C. SchoriLiang (ed.) European Right-Wing Populism and Foreign Policy, Aldershot, Ashgate.

Grunberg, G. and E. Schweisguth (2003) 'French political space. Two, three or four blocs?', in French Politics, vol. 1 no. 3, pp. 331-347.

Ivaldi, G. (1998) 'Le Front National à l'assaut du système', Revue Politique et Parlementaire, no. 995, pp. 5-22.

Ivaldi, G. (1999a) 'La liste Pasqua-De Villiers aux élections européennes du 13 juin 1999', Revue Française de Science Politique, vol. 49 no 4/5, pp. 643-652. 
Ivaldi, G. (1999b) 'La scission du Front National', in Regards sur l'actualité, no. 251, pp. 17-32.

Ivaldi, G. (2001) 'Les formations d'extrême-droite: Front National et Mouvement National Républicain' in P. Bréchon (ed.) Les partis politiques français, Paris, La Documentation Française, pp. 15-38.

Ivaldi, G. (2002) 'Enjeux sécuritaires et droites populistes en Europe', in S. Roche (ed.) Sociologie de l'insécurité, Paris, Armand Colin, pp. 199-210.

Kitschelt, H. (1995) The Radical Right in Western Europe: a Comparative Analysis, Ann Arbor, University of Michigan Press.

Mayer, N. (2002) Ces Français qui votent Le Pen, Paris, Flammarion.

Parodi, J.-L. (1997) 'Proportionnalisation périodique, cohabitation, atomisation partisane: un triple défi pour le régime semi-présidentiel de la Cinquième République', Revue Française de Science Politique, vol. 47 no. 3/4, pp. 292-312.

Perrineau, P. (1997) Le Symptôme Le Pen, Paris, Fayard.

Swyngedouw, M. and G. Ivaldi (2001) 'The extreme right utopia in Belgium and France: the ideology of the Flemish Vlaams Blok and the French Front National', West European Politics, vol. 24/3: 1-22. 
Table 1 FN and MNR national election results (1983-2004)

\begin{tabular}{cccc}
\hline & Election & $\%$ & Post-1999 split \\
\hline 1984 & European & 11.4 & - \\
1986 & Legislatives & 9.8 & - \\
1988 & Presidential & 14.4 & - \\
1988 & Legislatives & 9.7 & - \\
1989 & European & 11.7 & - \\
1993 & Legislatives & 12.4 & - \\
1994 & European & 10.5 & - \\
1995 & Presidential & 15.0 & - \\
1997 & Legislatives & 15.1 & 5.8 FN \\
1999 & European & 9.1 & 3.3 MNR \\
2002 & Presidential & 19.2 & 16.9 Le Pen \\
& & 17.8 & 2.3 Mégret \\
2002 & Legislative & 12.4 & 1.1 FN \\
& & & 1.1 MNR \\
2004 & & & 0.2 Other ER \\
& European & 10.13 & 9.81 Le Pen \\
& & & 0.32 Mégret \\
\hline
\end{tabular}


Table 2 Sociological profile of FN and MNR candidates in June 2002 legislative elections

\begin{tabular}{lcc}
\hline & FN & MNR \\
& $(\mathrm{N}=566)$ & $(\mathrm{N}=569)$ \\
\hline Gender & & \\
Male & 51.4 & 58.9 \\
Female & 48.6 & 41.1 \\
Average age & 53.0 & 51.5 \\
Occupation & & \\
Farmers & 3.1 & 2.6 \\
Self-employed & 13.0 & 10.4 \\
Professions / upper managerial & 21.4 & 22.1 \\
Middle managerial & 7.8 & 7.4 \\
White-collar employees & 17.6 & 20.8 \\
Blue-collar & 1.9 & 3.6 \\
Retired & 23.7 & 23.1 \\
Other inactive & 11.6 & 10.0 \\
\hline
\end{tabular}


Table 3 Sociological profile of FN and MNR voters in the 2002 legislative and presidential elections

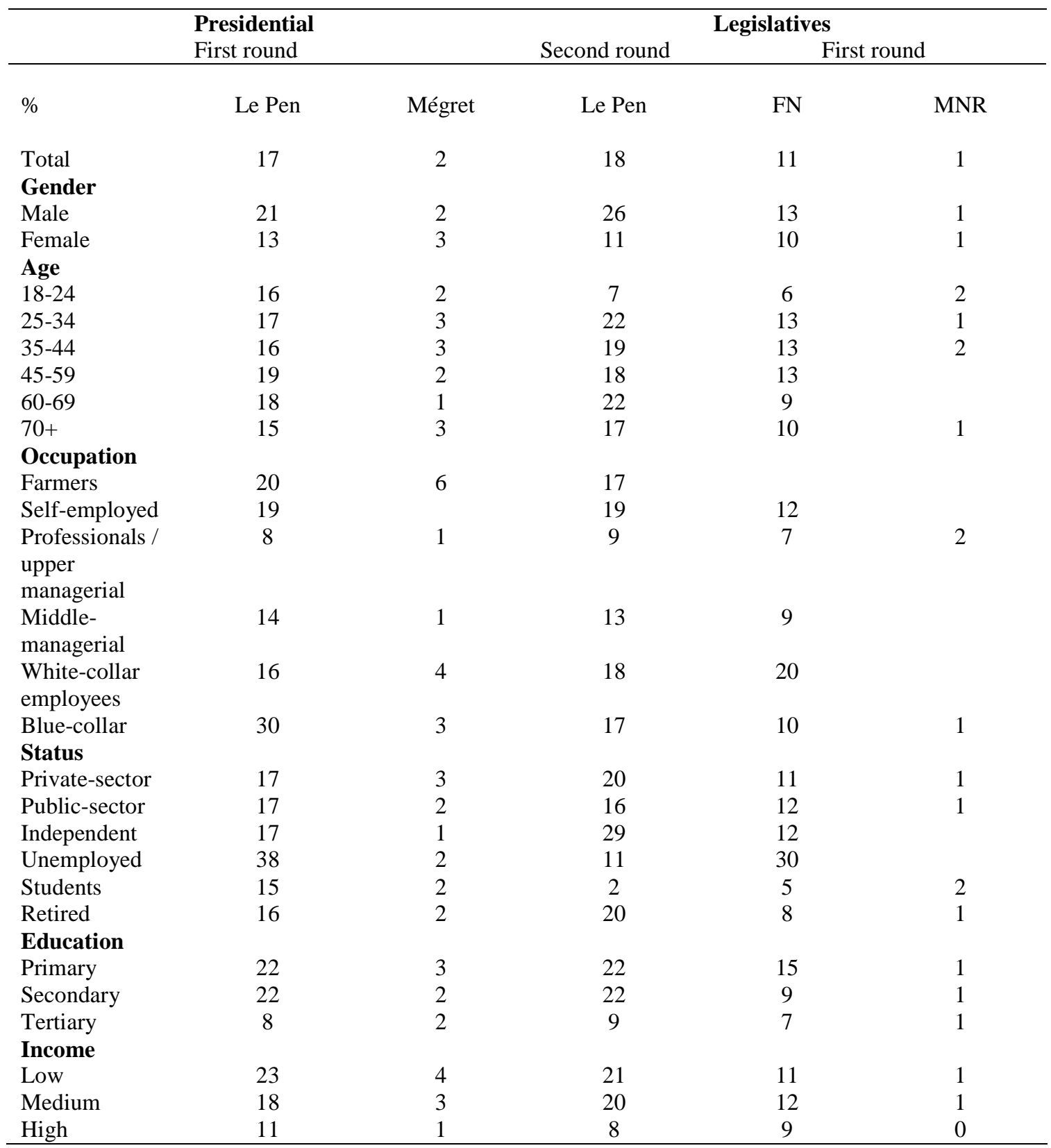

Source: IPSOS-Vizzavi-Le Figaro-France 2 surveys, 21 April, 5 May and 9 June 
Table 4 Territorial spread of Extreme Right vote in 2002

\begin{tabular}{|c|c|c|c|c|c|}
\hline \multicolumn{2}{|c|}{$\begin{array}{l}\text { Le Pen + Mégret, } 1^{\text {st }} \text { round } \\
\text { presidential } 2002\end{array}$} & \multicolumn{2}{|c|}{$\begin{array}{l}\text { Le Pen, } 2^{\text {nd }} \text { round presidential } \\
2002\end{array}$} & \multicolumn{2}{|c|}{$\begin{array}{l}\text { FN+MNR } 1^{\text {st }} \text { round legislatives } \\
2002\end{array}$} \\
\hline Vaucluse & 29.74 & Vaucluse & 29.64 & Vaucluse & 25.34 \\
\hline $\begin{array}{l}\text { Alpes- } \\
\text { Maritimes }\end{array}$ & 28.52 & Var & 28.69 & $\begin{array}{l}\text { Bouches-du- } \\
\text { Rhône }\end{array}$ & 21.83 \\
\hline Haut-Rhin & 28.51 & $\begin{array}{l}\text { Alpes- } \\
\text { Maritimes }\end{array}$ & 28.68 & Var & 21.65 \\
\hline Gard & 27.96 & $\begin{array}{l}\text { Bouches-du- } \\
\text { Rhône }\end{array}$ & 27.46 & $\begin{array}{l}\text { Alpes- } \\
\text { Maritimes }\end{array}$ & 21.16 \\
\hline $\begin{array}{l}\text { Bouches-du- } \\
\text { Rhône }\end{array}$ & 27.38 & Gard & 26.66 & Gard & 19.74 \\
\hline Bas-Rhin & 27.27 & $\begin{array}{l}\text { Pyrénées- } \\
\text { Orientales }\end{array}$ & 25.12 & Aube & 18.52 \\
\hline Moselle & 27.06 & Oise & 25.07 & Oise & 18.32 \\
\hline Var & 26.71 & Aisne & 24.57 & Hérault & 17.64 \\
\hline Ardennes & 26.52 & Hérault & 24.47 & $\begin{array}{l}\text { Pyrénées- } \\
\text { Orientales }\end{array}$ & 17.54 \\
\hline Belfort & 26.47 & Haute-Saône & 24.23 & Yonne & 17.48 \\
\hline Oise & 25.97 & Ardennes & 24.08 & Haut-Rhin & 17.43 \\
\hline Haute-Saône & 25.73 & Haute-Marne & 23.83 & Haute-Saône & 17.35 \\
\hline Hérault & 25.42 & Aube & 23.13 & Belfort & 17.00 \\
\hline Ain & 25.37 & Yonne & 22.67 & Haute-Marne & 16.64 \\
\hline Haute-Marne & 25.35 & Haut-Rhin & 22.35 & Ain & 16.47 \\
\hline Loire & 24.56 & Corse-du-Sud & 22.30 & Aisne & 16.28 \\
\hline Yonne & 24.44 & Pas-de-Calais & 22.19 & Loire & 15.84 \\
\hline Aube & 24.40 & Belfort & 22.08 & Eure & 15.82 \\
\hline Aisne & 23.83 & Aude & 22.07 & Nord & 15.68 \\
\hline Vosges & 23.75 & Lot-et-Garonne & 22.06 & Ardennes & 15.56 \\
\hline Drôme & 23.74 & Moselle & 21.88 & Eure-et-Loir & 15.56 \\
\hline $\begin{array}{l}\text { Pyrénées- } \\
\text { Orientales }\end{array}$ & 23.35 & Meuse & 21.78 & Moselle & 15.41 \\
\hline Meuse & 23.16 & Eure & 21.78 & Drôme & 15.33 \\
\hline Haute-Savoie & 23.13 & Somme & 21.74 & Aude & 15.30 \\
\hline $\begin{array}{l}\text { Tarn-et- } \\
\text { Garonne }\end{array}$ & 22.78 & Nord & 21.72 & Seine-St-Denis & 15.22 \\
\hline Savoie & 22.54 & $\begin{array}{l}\text { Tarn-et- } \\
\text { Garonne }\end{array}$ & 21.59 & Rhône & 15.02 \\
\hline Eure & 22.52 & Ain & 21.22 & Seine-et-Marne & 14.92 \\
\hline Loiret & 22.40 & Vosges & 21.19 & Bas-Rhin & 14.72 \\
\hline Aude & 22.30 & $\begin{array}{l}\text { Alpes-de- } \\
\text { Haute- } \\
\text { Provence }\end{array}$ & 21.17 & $\begin{array}{l}\text { Tarn-et- } \\
\text { Garonne }\end{array}$ & 14.70 \\
\hline Marne & 22.19 & Eure-et-Loir & 20.74 & Loiret & 14.52 \\
\hline
\end{tabular}


Table 5 Situation of the principal Extreme Right candidates in 2002 legislative elections

\begin{tabular}{|c|c|c|c|c|}
\hline \multirow[b]{2}{*}{ Candidate } & \multirow[b]{2}{*}{ Department } & \multicolumn{2}{|c|}{2002 legislatives } & \multirow[b]{2}{*}{ Configuration } \\
\hline & & $\begin{array}{l}\% \text { of vote } \\
1^{\text {st }} \text { round }\end{array}$ & $2^{\text {nd }}$ round & \\
\hline Carl Lang (FN) & Nord & 18.7 & & \\
\hline $\begin{array}{l}\text { Marine Le Pen } \\
\text { (FN) }\end{array}$ & Pas de Calais & 24.2 & 32.3 & Duel \\
\hline $\begin{array}{l}\text { Marie-France } \\
\text { Stirbois (FN) }\end{array}$ & Alpes-Maritimes & 23.0 & 20.1 & Triangular \\
\hline $\begin{array}{l}\text { Jacques Bompard } \\
\text { (FN) }\end{array}$ & Vaucluse & 34.1 & 42.4 & Duel \\
\hline $\begin{array}{l}\text { Jean-Claude } \\
\text { Martinez (FN) }\end{array}$ & Hérault & 20.1 & 17.2 & Triangular \\
\hline $\begin{array}{l}\text { Martine Lehideux } \\
\text { (FN) }\end{array}$ & Paris & 7.9 & & \\
\hline $\begin{array}{l}\text { Bruno Gollnisch } \\
\text { (FN) }\end{array}$ & Rhône & 23.2 & 21.3 & Triangular \\
\hline $\begin{array}{l}\text { Bruno Mégret } \\
\text { (MNR) }\end{array}$ & Bouches du Rhône & 18.6 & & \\
\hline $\begin{array}{l}\text { Jean-Yves Le } \\
\text { Gallou (MNR) }\end{array}$ & Hauts-de-Seine & 4.1 & & \\
\hline $\begin{array}{l}\text { Damien Bariller } \\
\text { (MNR) }\end{array}$ & Bouches du Rhône & 3.7 & & \\
\hline
\end{tabular}

